\title{
A Study on Flouting Maxims in Divergent Novel
}

\author{
Ernawati Fitri ${ }^{1}$, Laila Ulsi Qodriani $^{2}$ \\ ernanababan_brou@yahoo.com ${ }^{1},{ }^{2}$ ani@ @eknokrat.ac.id ${ }^{2}$ \\ STBA Teknokrat ${ }^{1,2}$
}

\begin{abstract}
This research focuses on flouting maxim in Divergent novel which aim is to find the types and the function of flouting maxim. The researchers used descriptive qualitative research because the researchers strived to analyze and discusses the sentences of utterances which performs flouting maxim in Divergent novel. This research uses pragmatic approach which uses Grice's theory of maxim. The result of this study shows that 21 data which are appropriated with the characteristic of flouting maxim. They consist of 12 flouting maxim of quantity, 2 flouting maxim of quality and 7 flouting maxim of relevance. Based on the data analysis the researchers concluded: the functions for flouting maxim of quantity are to explain more about topic, to stress something and unwillingness to cooperate; the functions for flouting maxim of quality are to show panic, to convince the addressee and to hide something; the functions for flouting maxim of relevance are to change the topic of conversation and to avoid talking about something.
\end{abstract}

Key Words: cooperative principle, flouting, pragmatics

\section{Introduction}

Human is social being who cannot live alone but human needs to interact to live. One of human activities in process of interaction is a communication. Good communication is needed in order to make the interaction runs smoothly and effectively. Listeners and speakers must speak cooperatively and mutually accept one another to be understood in a particular way. Paul Grice in Grundy (2000: 73) argues that "speaker intend to be cooperative is for speaker to give as much as information as is expected". They should conduct a rule in order to understand the implicit meaning of the utterances delivered. For this reason it is applied to make an effective communication in which there are at least two people engaged (speaker and hearer) and it is called as the cooperative principle.

The cooperative principle describes how people interact with one another. People who obey the cooperative principle in their language use will make sure that what they say in a conversation furthers the purpose of that conversation. Paul Grice (1975: 45) proposes four conversational maxims that arise from the pragmatics of natural language. The Grice's Maxims are a way to explain the link between utterances and what is understood from them. The principle describes how effective communication in conversation is achieved in common social situations and is further broken down into the four maxims of quality, quantity, relevance and manner. Maxim of quality means that our contribution has to be truthful and based on sufficient fact, maxim of quantity means that we have to make our conversational contribution such as required, maxim of relevance means that our utterance has to be relevant to the context of speech and maxim of manner means that we have to present the meaning clearly and avoid ambiguity.

Grice states that those four principles can be obeyed by the participant in conversation so that they can give contribution to the conversation and the conversation itself can go on smoothly. In fact, sometimes in communication, people do some strategy to make their conversation goes safe that is flouting maxims. Flouting the maxims means that speakers violate the conversational maxims, flouting is often done through figurative language. This strategy found in almost of our daily conversation, but occasionally we do not realize it because people tend to speak what is in their mind, they never think about the rules, especially rules of cooperative principle. When someone flouts maxims, they do some rhetorical strategies. Usually, we can find some flouting in the form of tautology, metaphor, overstatement, understatement, rhetorical question, and irony.

According to Cook (1989:31-32) there are times when meaning derives from deliberate violations. It can be happen in many ways. Quality flout, when communication degenerates into lying, or simply breaks down altogether. Quantity flout, when we say more than we need to mark a sense of occasion or respect; and when we say less than we need, perhaps to be rude or blunt. Relation flout, when communication turns into signal embarrassment or a desire to change the subject. Manner flout, when the information shared makes ambiguity, or it is violated either for humor. 
In this research, the researchers enthusiastically focuse on the study on flouting maxims since it is important to make communication go safe and more effective both in spoken and written communication and to make sentences more acceptable to the hearer. There are some reasons for maxim flouting to occur in a conversation. They are the amount of the information the speaker has, the truth of the information, and the relation of the utterance with the preceding utterance, and the obscurity and ambiguity of the utterance.

The research is conducted to investigate flouting maxims on the major characters of Divergent novel. The researchers are interested in using Divergent novel as the object of analysis because the uniqueness of the utterances of this novel that contains figurative language, because flouting maxims is often done through by figurative language. Flouting maxims of cooperative principles in this novel show the strong bond between the characters in their conversation. Moreover, the phenomena of flouting maxims in their conversation are signaling how their relationship as friends and also as a family. People usually pay more attention to the sentence structure in speech or spoken language because it will give the direct response from the hearers. In written language, however, the readers will respond the message if they understand the main idea of the written text. So that, the research will focus on what are the kinds of maxims flouted by the characters in Divergent novel.

\section{Research Method}

This research used library research as the primary data collecting. So, the researchers used some phases in this research. The first is reading phase, the second is indentifying phase and the last is classifying phase. In the process of analyzing the data, qualitative research is emphasized on the process analysis. The first is isting the utterances, which contain flouting maxims based on Grice's theory. The second is nalyzing the utterances which contain flouting maxims in order to make the research finding reports are clear and specific. The third is deciding which maxim are flouted in the conversation whether it is maxim of quantity, maxim of quality, maxim of relevance, or maxim of manner. The last is evaluating the data in order to put data accurately and coherently with the analysis by seeing the theory and the problems that relevant with the research.

\section{Findings and Discussion}

\subsection{Flouting Maxim of Quantity}

\section{Datum 1}

Tris : Why the hawk?

Tori : Never met a curious Abnegation before. In some parts of the ancient world, the hawk symbolized the sun. Back when I got this, I figured if I always had the sun on me, I wouldn't be afraid of the dark. (Divergent,2: 12)

The utterance is stated when the test begin after lunch. Tris sit at the long tables in the cafeteria, and the test administration call ten names at a time, one for each testing room. Tris walks into room 6 where Tori who is a Dauntless woman waits for Tris. Tris get confused looking at Tori because Tori busies herself with the machine on Tris right and asks "why the hawk?" and Tori response is "Never met a curious Abnegation before". The researchers classified Tori's response as flouting maxim of quantity since Tori gives too much information by delivering her opinion that "I figured if I always had the sun on me, I wouldn't be afraid of the dark." Because it remains Tori of the fear Tori have overcome.

Tori gives too much information is because Tori is trying to explain more about something that Tris ask. Usually someone tries to explain about something by giving much information and expecting that the hearer will understand more about the topic. Tori wants to make Tris understands more about the meaning of the hawk. Tori uses overstatement in response's Tris' question by explaining something in a way that makes it seem more important or more serious than it really is.

\section{Datum 2}

The other situation when Tori flouts the maxim of quantity is where she used a flout in order to give an insult or she described about the result of Tris's test.

Tris : Wait, so you have no idea what my aptitude is?

Tori : Yes and no. My conclusion is that you display equal aptitude for Abnegation, Dauntless, and Erudite. People who get this kind of result are... Divergent. (Divergent,3: 22) 
Tris done the simulation test and Tori walks back in. The result of Tris's simulation test was not sure. Typically, each stage of the simulation eliminates one or more of the function but in Tris's case, only two have been ruled out. That's why Tris curios with the result and asks, Tori flouts the maxim of quantity because Tori gives too much information than it requires, the answer should be "Yes and no. My conclusion," but Tori gives to much information by delivering her opinion "is that you display equal aptitude for Abnegation, Dauntless, and Erudite. People who get this kind of result are..."

Tori gives more informative contribution is to explain more about something. Tori does not only answer related to Tris's question but also Tori wants give more information about what aptitude that Tris's belong, so that Tris will understands more about her aptitude. Tori uses overstatement in response's Tris' question by stating something more than it actually is in order to make the point more serious.

\section{Datum 3} condition.

The instances when Tris was flouting the maxim of quantity were in situations where she described her

Caleb : Beatrice! What happened? Are you all right?

Tris : I'm fine when the test was over, I got sick. Must have been that liquid they gave us. I feel better now, though. (Divergent, 4: 28)

The conversation is stated when Tris is waiting for Caleb to arrive at home. Caleb arrives at home with Susan and her brother and Caleb asks Tris "What happened? Are you all right?" and Tris's answer "I'm fine." "When the test was over, I got sick. Must have been that liquid they gave us. I feel better now, though." Based on the datum above the researchers classified the datum as flouting maxim of quantity since Tris gives the contribution more informative than it requires. Besides, Tris can answer Caleb's question by say "I'm fine" only, but here Tris gives too much information to Caleb.

Tris flouts the maxim of quantity is because Tris does not want to make Caleb curious with Tris so Tris gives more explanation to Caleb by giving the answer "When the test was over, I got sick. Must have been that liquid they gave us. I feel better now, though." So Caleb will believe that Tris is fine. Tris's flouts the maxim of quantity by using overstatement because she gives the information more informative.

\section{Datum 4}

The dialogue happens when Christina and Tris are talking in the train. Christian has to shout over the wind, which blows harder through the open doors by the second. The train is picking up speed. Tris sit down. It will be easier to keep Tris balance if I'm low to the ground.

\section{Christina : Do you know where we're going?}

Tris : A fast train means wind, wind means falling out. Get down. I guess we're going to Dauntless headquarters, but I don't know where that is. (Divergent, 6: 51-52)

Christina raises an eyebrow at Tris and Christina asks Tris “do you know where we're going?” and Tris's answer is "A fast train means wind," and "Wind means falling out. Get down." Based on the datum about the researchers classified the datum as flouting maxim of quantity because Tris gives too much information by delivering her opinion "I guess we're going to Dauntless headquarters," "but I don't know where that is."

Tris gives too much information is to explain more about something that Christina asks. Tris not only answer the question but also Tris tries to explain the possible place that they are going. Tris flouts the maxim of quantity by using overstatement because she uses exaggeration statement "a fast train means wind, wind means falling out" therefore, the information is more informative.

\section{Datum 5}

Erudite girl : Rankings? Why are we ranked?

Eric : Your ranking serves two purposes, the first is that it determines the order in which you will select a job after initiation. There are only a few desirable positions available. The second purpose is that only the top ten initiates are made members. (Divergent, 7: 71)

The context of the conversation happens in Dauntless room after dinner between Eric and the mousyhaired Erudite girl in the first stage of initiation. The mousy-haired Erudite girl asks Eric "why are we ranked", she curios why they should be ranked. The answer of Eric is "Your ranking serves two purposes," he says. "The first 
is that it determines the order in which you will select a job after initiation. There are only a few desirable positions available." "The second purpose," he says, "is that only the top ten initiates are made members." Then, the researchers classified that Eric's statement as flouting maxim quantity since his contribution is not informative as is requires for the current purpose of the exchange and more informative than is required.

Eric flouts the maxim of quantity because he wants to give clear explanation to the hearer so the hearers will understands what the purposes they should be ranked. He delivers his statement by using overstatement in order to the information more informative.

\section{Datum 6}

Tris : Do they have to be so public?

$\mathrm{Al} \quad$ : She just kissed him, it's not like they're stripping naked. $\quad$ (Divergent, 8: 82)

This conversation occurs when the Dauntless faction have a time for lunch. Edward and Myra, the other Erudite transfers, sit two tables away, so close they bump elbows as they cut their food. Myra pauses to kiss Edward. Tris is watching them carefully. Tris has only seen a few kisses in her life. Edward turns his head and presses his lips to Myra's. Air hisses between her teeth, and Tris looks away. Tris asks Al why they have to kissing in public and $\mathrm{Al}$ answer is "She just kissed him." $\mathrm{Al}$ frowns at Tris. When $\mathrm{Al}$ frowns, his thick eyebrows touch his eyelashes. By see Al's response "It's not like they're stripping naked." the researchers classified the conversation as flouting maxim of quantity because $\mathrm{Al}$ gives Tris more information than is requires by answering "She just kissed him. It's not like they're stripping naked."

By giving too much contribution in the conversation above, it means that Al flouts the maxim of quantity through overstatement. Al flouts the maxim of quantity is because $\mathrm{Al}$ wants to give his opinion to Tris that they are only kissing not stripping naked, so don not take it seriously.

\section{Datum 7}

The dialogue occus when Four leads Christina and Tris to a new room, still in Dauntless room and Al, who was in front of them, turns around once they reach the Pit and announces that he wants to get a tattoo.

Will : A tattoo of what?

Al : I don't know. I just want to feel like I've actually left the old faction. Stop crying about it. (Divergent, 8: 85)

Will asks $\mathrm{Al}$ what tattoo that $\mathrm{Al}$ wants and $\mathrm{Al}$ answer is "I don't know." $\mathrm{Al}$ laughs. "I just want to feel like I've actually left the old faction. Stop crying about it." Based on the conversation above the researchers classified the datum as flouting maxim of quantity since Tris gives too much contribution when answering Will's question. Actually, Tris can say "I don't know." But here Tris adds her opinion by saying "I just want to feel like I've actually left the old faction. Stop crying about it."

Based on the analysis above Tris flouts the maxim of quantity by using overstatement because Tris wants to give more informative contribution than is requires. Tris wants to make clear information that Tris wants to feel like she has actually left the old faction.

\section{Datum 8}

The instance where Tori flouted the maxim of quantity happened when she described her job.

Tori : Well, hello there. Never thought I would see you again. Beatrice, is It?

Tris : Tris, actually. Do you work here?

Tori : I do. Ijust took a break to administer the tests. Most of the time I'm here. I recognize that name. You were the first jumper, weren't you?

Tris : Yes, I was. (Divergent, 8:89)

The dialogue happens in the tattoo place when a picture of a hawk reminds Tris of Tori's tattoo. Tris turns to see Tori standing there, Tris feels like she back in the aptitude test room. Tris did not expect to see her again. Tris asks Tori "do you work here" and Tori's answer is "I do. I just took a break to administer the tests. Most of the time I'm here." Tori taps her chin. "I recognize that name. You were the first jumper, weren't you?" then, the researches classifies Tori's statements as flouting maxim of quantity since she gives too much information. Actually, she can answer "yes or no" but she gives the contribution more than is required. 
Based on the analysis above, Tori uses overstatement to flout the maxim of quantity because she wants to give clear information about her work and she also wants to change the topic by asking Tris question "I recognize that name. You were the first jumper, weren't you?" Tori wants to make the conversation go smoothly.

\title{
Datum 9
}

The utterance is stated when Tris and Tori in tattoo room and Tori asks Tris whether Tris wants to make a tattoo or not.

\author{
Tori : Want a tattoo? \\ Tris : Yes, three of these flying birds. (Divergent, 8: 90)
}

Tris's response is "Yes," Tris says "Three of these flying birds." The researchers classified that Tris's response as floting maxim of quantity by using overstatement since Tris gives more contribution than it requires by saying "Three of these flying birds." Tris flouts the maxim of quantity because she wants to give clear information about what kind of tattoo that she wants. She said "Three of these flying birds." because she is marking the path of flight toward her heart. One for each member of the family she left behind.

\section{Datum 10}

This conversation below belongs to flouting maxim of quantity.

Tris : What's wrong with them?

Christina : Peter is pure evil. When we were kids, he would pick fights with people from other factions and then, when an adult came to break it up, he'd cry and make up some story about how the other kid started it. And of course, they believed him, because we were Candor and we couldn't lie. Ha ha. Drew is just his sidekick. I doubt he has an independent thought in his brain. And Molly...she's the kind of person who fries ants with a magnifying glass just to watch them flail around. (Divergent, 9: 93)

The dialogue happens in the Dauntless training room when Christina points at Peter, Drew, and Molly. They have been inseparable since they crawled out of the womb, practically. Christina hates them. Tris is glance at Peter and his friends. Drew is shorter than both Peter and Molly, but he's built like a boulder, and his shoulders are always hunched. His hair is orange-red, the color of an old carrot. Tris asks Christina what's wrong with them and Christina answer Tris's question by saying "Peter is pure evil. When we were kids, he would pick fights with people from other factions and then, when an adult came to break it up, he'd cry and make up some story about how the other kid started it. And of course, they believed him, because we were Candor and we couldn't lie. Ha ha." Christina wrinkles her nose and adds, "Drew is just his sidekick. I doubt he has an independent thought in his brain. And Molly...she's the kind of person who fries ants with a magnifying glass just to watch them flail around." Christina gives too much information about them and the researchers classifies the datum as flouting maxim of quantity since Christina gives too much contribution to answer Tris's question.

Based on the analysis above Christina uses overstatement in answer Tris's question and she flouts the maxim of quantity is because Christina wants to give clear explanation also information about Peter, Drew, and Molly. So Tris can undersatan what's wrong with three of them.

\section{Datum 11}

The conversation below happens in the night at training room when Tris talks to Al. Tris asks $\mathrm{Al}$ whether Will is ok or not because previously Will and $\mathrm{Al}$ have been fighting.

Tris : Did you talk to Will? After...you know.

Al : Yeah. He's fine. He isn't angry. Now I'll always be remembered as the first guy who knocked someone out cold. (Divergent, 10: 106)

Based on the dialogue above the researchers classified Al's answer as flouting maxim of quantity since Al gives too much information and Al use exaggeration statement (now I'll always be remembered as the first guy who knocked someone out cold) therefore, his information is more informative. Actually, Al's response should be "yes or no" but he gives too much contribution to answer Tris's question. Al flouts the maxim of quantity because Al wants to give clear information to Tris. Al's answer is "Yeah. He's fine. He isn't angry." It means that Will does not angry to $\mathrm{Al}$ and everything is alright. 


\section{Datum 12}

This conversation happens between $\mathrm{Al}$ and Tris in the hospital.

Al : You feeling okay, Tris?

Tris $\quad$ : Yeah, just wish I could stay here forever so I never have to see Peter again. (Divergent, 10: 112-113)

The context happens when Tris have been fighting with Peter. Tris wake up and she feels inside of her head is fuzzy like it's packed with cotton balls. Al asks Tris whether she is ok or not because Tris looks like she keeping the pain and Tris's answer "Yeah," Tris says "Just wish I could stay here forever so I never have to see Peter again." Based on the analysis above the researchers classified the datum as flouting maxim quantity because Tris give more contribution than it requires by saying "Just wish I could stay here forever so I never have to see Peter again." Besides, she should answer Al's question by saying “yes or no.”

Tris flouts the maxim of quantity is because Tris wants give more information by saying "Just wish I could stay here forever so I never have to see Peter again." It means that she exaggerations her statement by using overstatement and she does not want to see Peter again because she hates Peter.

\subsection{Flouting Maxim of Quality}

\section{Datum 13}

$\begin{array}{ll}\text { Tris } & \text { : What? } \\ \text { Christina } & \text { : I'm developing a theory. } \\ \text { Tris } & : \text { And it is? } \\ \text { Christina } & \text { : That you have a death wish. (Divergent, 7: 69) }\end{array}$

This conversation takes place in Dauntless room between Christina and Tris after Tris talk to Four and Four remains Tris that Tris should be careful. When Christina states "that you have a death wish" she overtly flouts the maxim of quality by using overstatement. She says what he believes to be false. She flouts the maxim of quality because her contribution is not true and she says something for which lacks adequate evidence.

\section{Datum 14}

The dialogue happens when Four leads Christina and Tris to a new room, still in Dauntless room. Christina states "I'm surprised he didn't break you in half" "He scares the hell out of me. It's that quiet voice he uses." Her contribution is not true and she says something for which lacks adequate evidence because she uses overstatement when she talks to Tris. So the researchers classified the datum as flouting maxim of quality.

Christina : I'm surprised he didn't break you in half, he scares the hell out of me. It's that quiet voice he uses.

Tris : Yeah. He's...definitely intimidating (Divergent, 8: 85)

Based on the analysis above, Christina flouts the maxim of quality because she uses overstatement in delivering her opinion, she thinks that Four is a bad person and it scares Christina and Tris. It's not true that Four is a bad person because at the end Four kept both of them. Christina flouts the maxim of quality is because she says what he believes to be false.

\subsection{Flouting Maxim of Relevance}

\section{Datum 15}

The utterance is stated when Tris and her mother are talking in front of mirror.

Tris's mother : So today is the day,

Tris : Yes,

Tris's mother : Are you nervous?

Tris : Today is the day of the aptitude test that will show me which of the five factions I belong in. And tomorrow, at the Choosing Ceremony, I will decide on a faction; I will decide the rest of my life; I will decide to stay with my family or abandon them. (Divergent, 1: 2) 
Her mother asks Tris whether she is nervous or not because today is the day of the aptitude test. But, Tris's answer is "Today is the day of the aptitude test that will show me which of the five factions I belong in. And tomorrow, at the Choosing Ceremony, I will decide on a faction; I will decide the rest of my life; I will decide to stay with my family or abandon them." Tris's response is not relevant at all to her mother's question. Then, the researchers classified Tris's statement as flouting maxim of relevance.

People are said to flout the maxim of relevant when he or she gives irrelevant answer to the topic being talked. One of the reasons for flouting maxim of relevant is to give unnecessary additional information. We see that Tris's statement is not necessary because it does not answer her mother's question. Tris flouts the maxim of relevance by using understatement because she gives less informative statement.

\section{Datum 16}

The context of the utterances is in the test room between Tris and Tori when Tori stands behind Tris. Tori passes Tris a vial of clear liquid and ask Tris to drink it but Tris feels curious about the clear liquid and Tris asks Tori "what is it?" and Tori answers "Can't tell you that. Just trust me." The researchers classified Tori's response as flouting maxim of relevance since Tori's response is not relevant to Tris's question.

Tori : Drink this,

Tris : What is it? What's going to happen?

Tori : : Can't tell you that. Just trust me. (Divergent,2: 13)

Tori is flouting the maxim of relevance through understatement because Tori makes a situation seem important than it is. Tori flouts the maxim of relevance because she wants to avoid talking something. Tori does not want to response Tris's question because this is the beginning of the tests, so Tori cannot tell anything to Tris because nobody knows what happens with the test.

\section{Datum 17}

The conversation below takes places in the school cafeteria when Tris do the tests. On the table there are two baskets in front of Tris, in one is a hunk of cheese, and in the other, a knife the length of my forearm.

$\begin{array}{ll}\text { The woman } & : \text { Choose } \\ \text { Tris } & : \text { Why? } \\ \text { The woman } & : \text { Choose, choose! (Divergent, 2: 13-14) }\end{array}$

The woman asks Tris to choose one of them but Tris get confused why she wants Tris to choose one of them. The woman repeats her statement "choose" for three times. The researchers classified the woman's statement as flouting maxim of relevance since her statement does not relevant to Tris's question.

The woman does not to answer Tris's question because this is one of the tests that Tris have to pass but Tris does not aware that she still in the simulation test, so the woman flouts the maxim of relevance is to avoid talking something. The way the woman responses Tris's question is because the woman is generating implicature by saying less than is required.

\section{Datum 18}

Tris

: Did you two take the bus today?

Susan $\quad$ :Our father had to work late and he told us we should spend some time thinking before the ceremony tomorrow. (Divergent, 4: 29)

The conversation occurs when Tris is waiting for Caleb to arrive at home. Caleb arrives at home with Susan and her brother. Tris asks Susan and her brother did them take the bus today and Susan answer is "Our father had to work late," Susan says, "and he told us we should spend some time thinking before the ceremony tomorrow." Based on the conversation above the researchers classified the datum as flouting maxim of relevance since Susan's response is irrelevant to Tris's question.

Susan flouts the maxim of relevance by using understatement because she gives less informative statement to Tris's question. Susan flouts the maxim of relevance is because Susan wants to change the topic by saying "Our father had to work late and he told us we should spend some time thinking before the ceremony tomorrow." She does not answering Tris's question did both of them take the bus today or not. 


\section{Datum 19}

The dialogue below happens between Tris and Caleb in their home. While Caleb curios about the result of Tris's test so he asks Tris "Are you going to tell me the truth now?" and Tris's response is "I'm not supposed to discuss it. And you're not supposed to ask." Then, the researchers classified Tris's answer as floting maxim of relevance since Tris's answer is not relevant to Caleb's question.

Caleb : Are you going to tell me the truth now?

Tris : The truth is, I'm not supposed to discuss it. And you're not supposed to ask. (Divergent,4: 2930)

Tris does not want to discuss the result of her simulation test to Caleb because Tori told to Tris that Tris should not share the result with anyone, no matter happens. So Tris flouts the maxim of relevance to avoid talking about the result because Tris wants to keep the result. Tris is flouting the maxim of relevance through understatement because Tris gives the statement that is less than complete.

\section{Datum 20}

Tris : : Are you two...friends?

Four $\quad$ :We were in the same initiate class, he transferred from Erudite. (Divergent, 7: 68)

The conversation above happens in Dauntless room between Tris and Four, Tris asking something after Eric talk with Four. Tris feels curios whether both of them are friends or not. So, Tris asks Four are they friends or not and Four's answer is "We were in the same initiate class," "He transferred from Erudite." The answer should be yes or no but Four intends to communicate more than what is said. The researchers sclassified Four's response as flouting maxim of relevance since his response is irrelevant to Tris's question.

Four and Eric have bad relationship as a friends because Eric does not like Four, but Four does not want Tris know about it. That's why Four flouts the maxim of relevance to avoid something. Four flouts the maxim of relevance by using understatement because He gives less informative statement and his statement is not relevant to Tris's question.

\section{Datum 21}

The conversation is stated when Will and Christina break for lunch and Will come to Christina and asks her whether He can sit near Christina or not. Christina's response is "What, you don't want to hang out with your Erudite buddies?."
Will
: Can I sit here?
Christina
:What, you don't want to hang out with your Erudite buddies? (Divergent, 8 : 81)

Based on the analysis above the researchers classified Christina's statement as flouting maxim of relevance since she uses understatement tin delivering her statement because her statement is less informative and her answer is not relevant to Will's question. Christina flouts the maxim of relevance because she wants to change the topic. Both of them are in different faction so Christina thinks that they are not friends anymore and suggest Will to hang out with his Erudite buddies but Will has different opinion. Will does not want get along with Erudite people.

\section{Conclusion}

This study is conducted to find the types and the function maxims are flouted used in Divergent novel. The researchers used Grice's theory in analyzing the data. After analyzing the data, the researchers found twenty one data which are appropriate with the characteristics of flouting. They consist of twelve flouting maxim of quantity, two flouting maxim of quality and seven flouting maxim of relevance. The researchers did not find the data that shows flouting maxim of manner. The strategies that the researchers found in flouting maxims of this novel are done through overstatements and understatements.

Based on the data analysis above the researchers conclude that the characters flouts the maxim of quantity by giving much information because they want to explain more about the topic and to stress something so that the hearer has clear understanding. Vice versa, the characters flout the maxim of quantity by giving less informative contribution because they do not want to corporate. The characters flout the maxim of quality by using theoretical question to show panic and to convince the addressees, in the other hand the characters flout the maxim of quality 
by saying something they belive to be false because they want to hide something. The characters chose to flout the maxim of relevance by giving irrelevant contribution because they want to change the topic of the conversation and they want to avoid taking about something.

\section{References}

Brown, Gillian, Goerge Yule. 1983. Discourse Analysis. Cambridge: Cambridge University Press.

Cook, Guy. 1989. Discourse. Oxford: University Press.

Cutting, Joan. 2002. Pragmatics and Discourse, a Resource Book for Student. New York: Routledge.

Cruse, A. 2000. Meaning in Language:An Introduction to Semantics and Pragmatics. Cambridge: Cambridge University Press.

Finch, Geoffrey. 1988. How to Study Linguistics. London: Macmillan Press Ltd.

Finegan, E. 2004. Language its structure and Use Fourth Edition. Massachusetts: Thomson Wadsworth.

Goody, E. 1996. Questions and Politeness. Cambridge: Cambridge University Press.

Grice, H. Paul. 1975. Logic and Conversation. New York: Oxford University Press.

Grice, H. Paul. 2004. Conversational Implicature;Cooperative Principle Online :http://www.art scl.wustl.edu/MindDict/grice.html.

Grundy, P. 2000. Doing pragmatics. (Second Edition). New York: Oxford Press.

Leech, G. 1983. Principle of Pragmatics. London: Longman

Levinson, S C. 1983. Pragmatics. Cambridge: Cambridge University Press

Markkanen, Raija. 1997. Hedging and Discourse: approaches to the Analysis of a Pragmatics Phenomenon in Academic Texts. New York: de Gruyter.

Nugroho, A. 2002. "The Contradiction of Certainty and Uncertainty in Hedging and Its Implications to Language Teaching" in Journal: A biannual publication on the study of language and literature (vol4/No. 1/ June 2002 p 17-22). Surabaya: Petra Christian University

Roth, Veronica.2011. Divergent. New York: Katherine Tegan Books.

Thomas, J. (1995). Meaning in Interaction: an Introduction to Pragmatics. Harlow: Pearson Education

Yule, G. 1985. The Study of Language: An introduction. Cambridge: Cambridge University Press.

Yule, G. 1996. Pragmatics. New York: Oxford University Press.

Widdowson, H. G. 2007. Discourse Analysis. Oxford: Oxford University Press. 